\title{
Subglacial deposition and deformation of stratified drift at the formation of tills beneath an active glacier - an example from Skåne, Sweden
}

\author{
M. ÅMARK
}

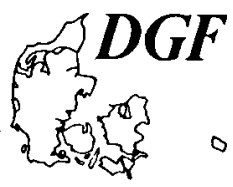

Amark, M.: Subglacial deposition and deformation of stratified drift at the formation of tills beneath an active glacier - an example from Skåne, Sweden. Bull. geol. Soc. Denmark, vol. 34, pp. 75-81, Copenhagen, May, 30th, 1985. https://doi.org/10.37570/bgsd -1985 -34-07

\begin{abstract}
Two tills at Grönalund in Skåne, southern Sweden, have been investigated. The tills are basal tills and were deposited beneath an active glacier. The material constituting the tills is partly melted out, far-travelled and englacially transported debris and is partly derived from the local bedrock. Main factors contributing to the formation of the tills were: 1 . The action of subglacial melt-water which resulted in strata of gravel and sand. 2. The deformation and mixing of this material by the movingglacier which partially resulted in diffusely laminated and poorly sorted material.
\end{abstract}

Max Åmark, Department of Quaternary Geology, Sölvegatan 13, S-223 62 Lund, Sweden, December 16th 1982.

Basal tills have been classified by Sugden \& John (1976) according to the way they have formed. Lodgement tills are formed by lodging beneath an active glacier. Basal melt-out tills have formed by the accumulation of melted out debris from a stagnant glacier or from the stagnant glacier ice beneath an active glacier. Flow of till induced by pressure differences beneath a glacier leads to a subglacial flow till. A deformation till results when an active glacier deforms the substratum. Consequently, release of the debris transported in a glacier results either in a lodgement till or a basal melt-out till. The only difference between the genesis of these two tills is the activity of the glacier, as also the lodging process includes basal melting of the glacier. Melt-out results in a structureless or massive till unless the debris in the glacier is stratified (Shaw 1977). A basal melt-out till may contain stratified drift due to the action of subglacial melt-water during the deposition of the till (Shaw 1979).

According to several authors, stratified drift does either not occur or else only occurs in small amounts in a lodgement till (Boulton 1970; Boulton \& Dent 1974; Boulton, Dent \& Morris 1974; Humlum 1979; Krüger 1979; Krüger \& Humlum 1980). However, this investigation shows that not only the melt-out of debris but also the action of subglacial melt-water may be of importance during the deposition of tills beneath an active glacier. The investigated tills are to a considerable extent made up of stratified drift that was deposited and deformed simultaneously with the meltout of debris from the glacier.

This investigation was presented at the INQUA \& IGCP Field Meeting in Denmark in 1981 dealing with glacial tectonics. The purpose of the presentation was to exemplify small-scale and syndepositional glaciotectonic deformation of till. The investigated site, which comprises a number of sections in till, will be described at length in the 'Thesis Series' of the Department of Quaternary Geology, University of Lund, Sweden.

\section{Methods}

The walls of the exposures were carefully cleaned. At first, the tills seemed to be more or less massive and stratification stood out clearly only on even, fresh and moist surfaces. The site was documented with about 150 slides, from which the drawings below were made.

Microscopic determination of the petrography in the size-fraction 3-11 $\mathrm{mm}$ was carried out in 


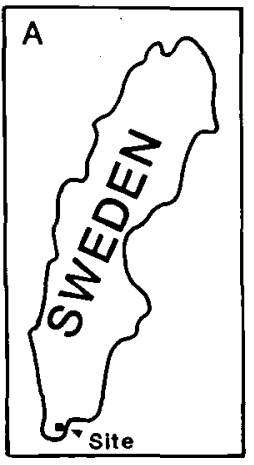

E. Granite

\section{Diabase}

Q Syenite

Limy sandstone and sandy limestone

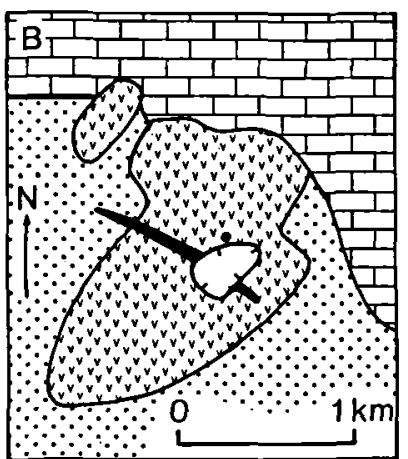

Quarry

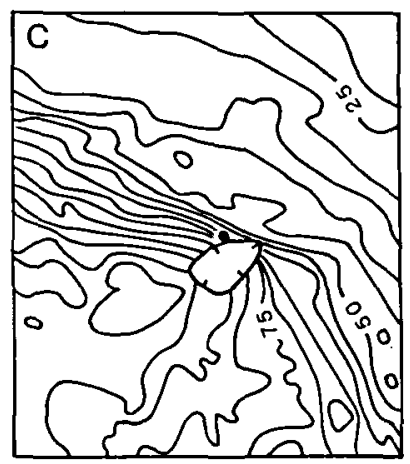

Fig. 1. The till excavations at Grönalund quarry. A. The location of the quarry. B. The bedrock in the area around the quarry. The location of the investigated area is marked with a dot. C. Topography. The map covers the same area as the one in Fig. 1B. D. The investigated area with till excavations.

the laboratory. The individual samples comprised 900-1300 grains. The petrography of coarser material was determined in the field by visual exam: ination.

\section{Description}

The excavations are located on the north-eastern slope of the horst Nävlingeåsen, immediately north of Grönalund quarry (Figs. 1B and C) and $2.5 \mathrm{~km}$ south-west of the village of Önnestad. The uncovered bedrock is brownish-black and consists of syenite, quartz syenite and monzonite (Kornfält, Bergström, Carserud, Henkel \& Sundquist 1978). Its extent as well as the surrounding bedrock (Kornfält et al. 1978) is shown in Fig. 1B. For the sake of simplicity, the word syenite will be used in the text. Sandy limestone and limy sandstone extends about $5 \mathrm{~km}$ north and

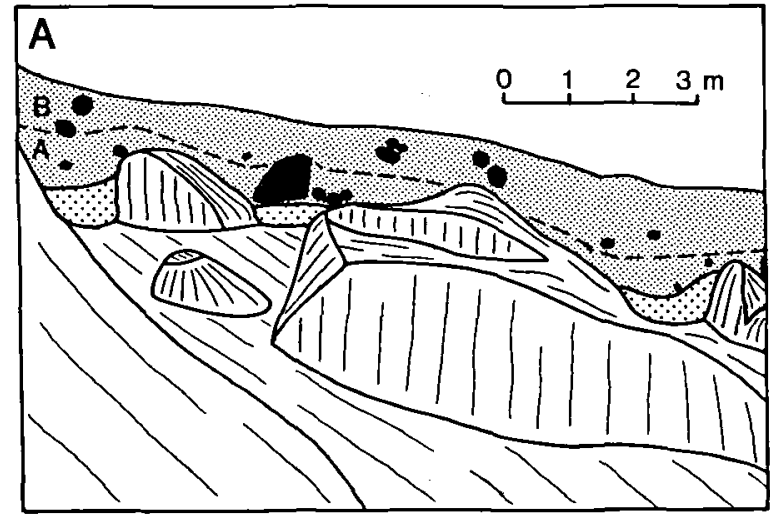

四 Bedrock. Syenite A Till. Rich in syenite

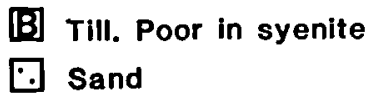

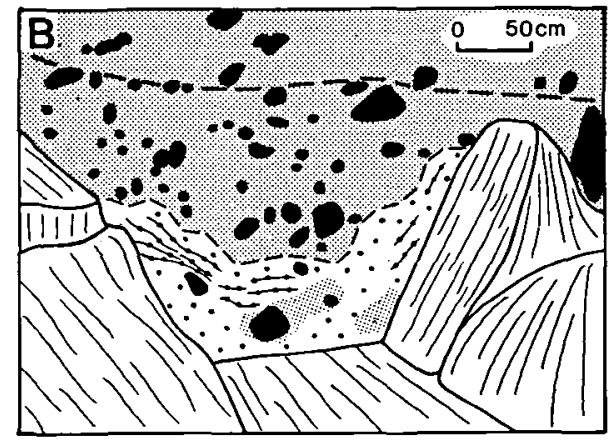

Sand

Fig. 2. Section 1. A. The northern part of the section. The jrregular surface of the uncovered syenite bedrock is seen in front of the vertical wall with drift. The till is underlain by sand in the troughs between the bedrock knobs. B. The southernmost body of sand in Fig. 2A. 


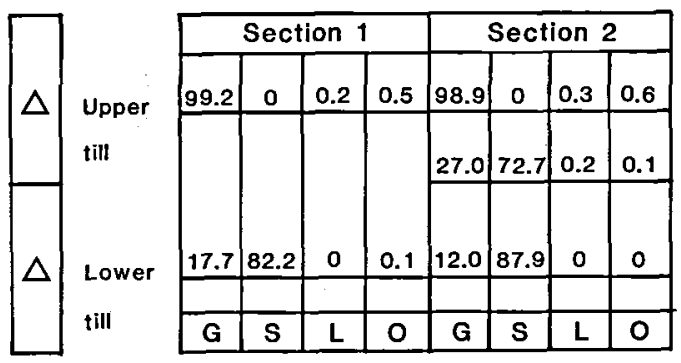

Table 1. The petrographic composition in the size-fraction 3-11 $\mathrm{mm}$ of the lower and the upper till. The numbers show the percentage of the individual bedrock types. $\mathrm{G}=$ Granite and gneiss. $\mathrm{S}=$ Syenite. $\mathrm{L}=\mathrm{Limy}$ sandstone and sandy limestone. $\mathrm{O}=$ Other kind of bedrocks.

north-east of the site, where they are replaced by gneiss, granite and restricted outcrops of syenite (Bergström \& Shaik 1980).

The surface of the uncovered bedrock is uneven (Fig. 2). The top surfaces and the north-facing upper parts of the bedrock knobs are striated (Fig. 1D). Like the glacial striae of the surrounding areas these striae indicate movement of ice from about $\mathrm{N} 20^{\circ} \mathrm{E}$.

The glacial drift comprises two tills. The boulders, stones and gravel are mostly of brownishblack syenite in the lower, blackish till. Here, as well as in the upper till, the sand-size fraction is mostly made up of red feldspar and transparent quartz grains. Gneiss and granite make up gravel and coarser material in the upper, light-grey or yellowish-grey till. The petrographic composition of the size-fraction $3-11 \mathrm{~mm}$ is illustrated in Table
1. Microscopic analysis revealed that the sandsized quartz and feldspar grains are not derived from the syenite bedrock. Syenite was not found in a till resting on limestone bedrock at a site located $800 \mathrm{~m}$ east of Grönalund quarry.

Fig. 2A shows the northernmost part of section 1 (Fig. 1D). Laminated sand occurs between the bedrock knobs. The sand contains clasts of syenite and is partly mixed with diffusely laminated, unsorted or poorly sorted material (Fig. 2B). Strata of laminated sand in the tills are parallel to the boundary between the upper and lower tills.

The upper till is exposed in section 2, the central part of which is demonstrated in Fig. 3A. Strata of sand are roughly horisontal in the bottom part of the section and folded in the upper part. Fig. 4 is a close up of a fold. The fold-axes are of varying direction, but are generally perpendicular to the neighbouring glacial striae (Fig. $3 \mathrm{~A}$ inset). A bent stratum of mostly laminated, gravelly sand and sand, part of which dips steeply, occurs in the eastern part of section 2 (Fig. $3 B)$. Its strike $\left(100^{\circ}\right)$ is marked in the inset in Fig. $3 \mathrm{~A}$. The till in section 2 consists of well-defined and distinctly laminated strata of sand, irregularly and diffusely laminated bodies of sand, strata and bodies of sandy gravel and partly stony gravel and bodies of unsorted sandy gravelly material (Fig. 5). Stones and boulders also occur.

Fig. 6 shows a small part of section 3. Low-angle faults occur in the roughly horisontal strata of sand, with steeply dipping lamination in the lower part of the figure. The faults indicate a de-
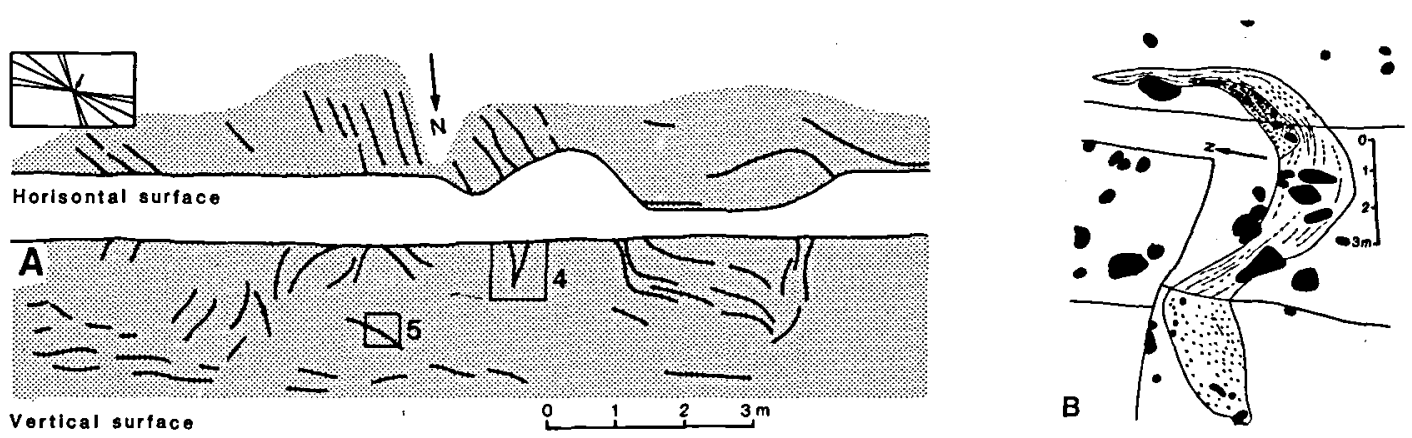

Fig. 3. Section 2. A. Laminated and folded strata with well-defined boundaries in a horisontal and vertical cut in the middle part of section 2. The strike of the fold-axes and the mean direction of the glacial striae (Fig. 1D) are shown in the inset in the upper left corner of the figure. The framed areas in the vertical section are covered by Figs. 4 and 5. B. Stratum of laminated sand in the eastern part of section 2 . 


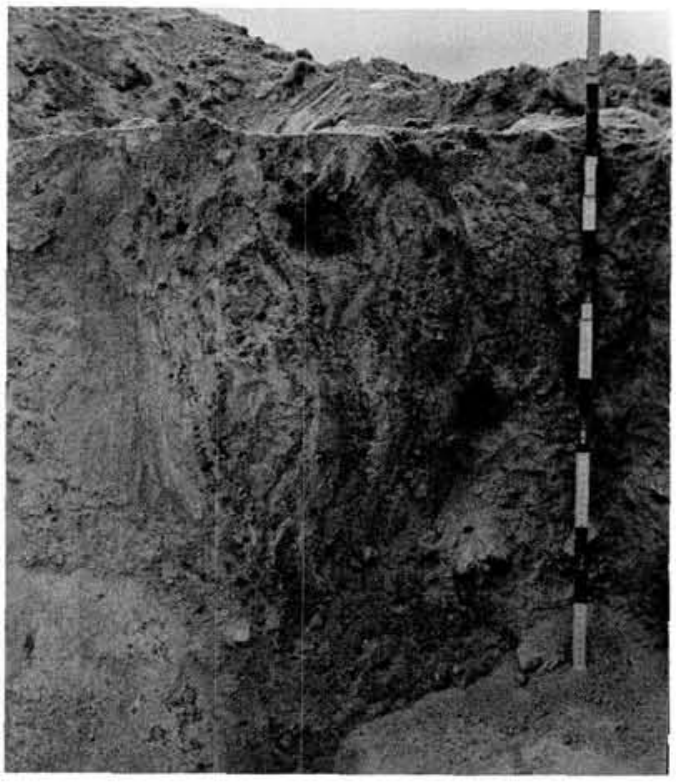

Fig. 4. Folded strata in section 2. The figure covers the square marked with the number 4 in Fig. 3. Two boulders occur in the lower part of the figure. The divisions of the folding rule are 10 $\mathrm{cm}$.

formational force from the north. Above occur irregular bodies of laminated sand as well as unsorted sandy and sandy gravelly material.

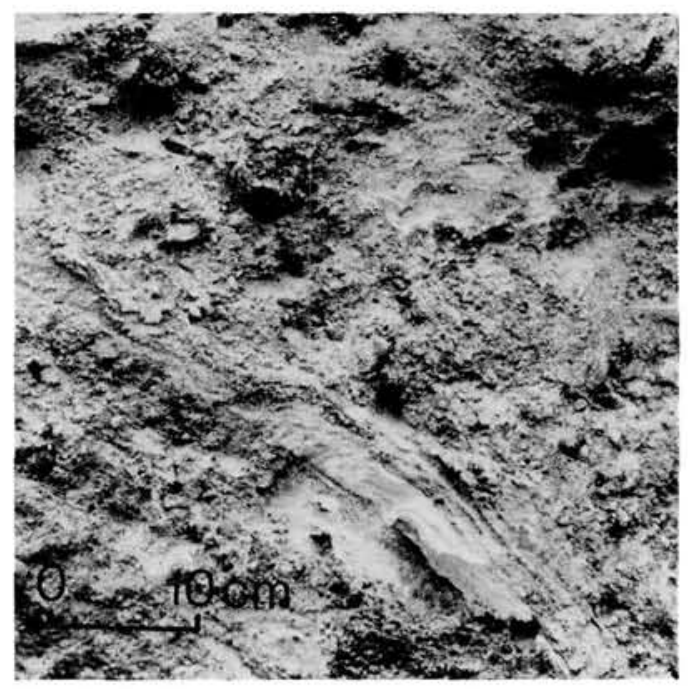

Fig. 5. Close up of the till in section 2. The figure covers the square marked with the number 5 in Fig. 3. A bed of sand that dips to the right is seen in the middle part of the figure. Irregular and diffusely laminated bodies of sand stand out light grey. Irregular bodies of sandy gravel and unsorted sandy gravelly material stand out dark grey.

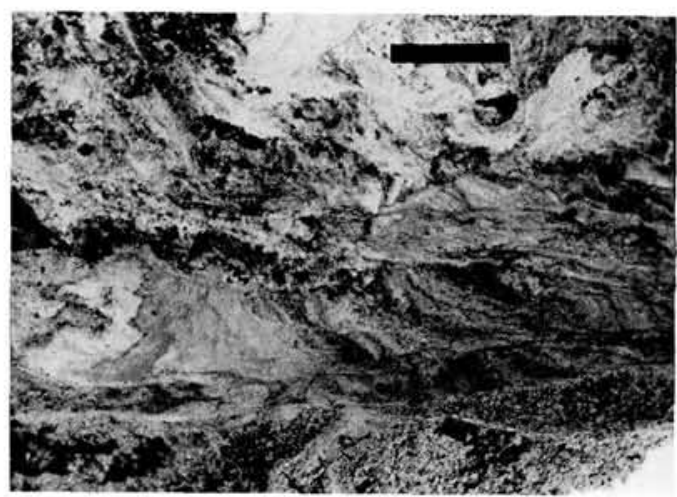

Fig. 6. Deformed and laminated sand in section 3. The bar in the uppermost part of the figure is $10 \mathrm{~cm}$ long.

The surface of the bedrock dips to the north in section 4 (Fig. 7). The upper part of the bedrock is fractured. Two fracture systems occur: One parallel to the bedrock surface and one dipping about $30^{\circ}$ to the south. The fractures are filled with sand which is laminated parallel to the extension of the fractures. The sand passes gradually into the overlying till. The transition between the bedrock and the till is gradual in some spots. Strata of sand with well-defined boundaries and distinct lamination lie mainly parallel to the bedrock surface. The lamination is generally parallel to the extension of the strata, but inclined laminae are also found (Figs. 8 and 9). Low-angle faults indicate a southerly directed deformational force. There are gradual transitions between the distinctly laminated and well-defined sub-horisontal strata of sand and the irregular, massive or faintly laminated bodies of sand. Bodies of gravel as well as unsorted gravelly-sandy material occur. In Fig. 7, only the sand strata in the lower part of the upper till are marked, as only here careful observations were possible.

\section{Results}

The fractures filled with sand in section 4 are of glacial origin, as they do not coincide with the fractures which control the bedrock morphology. They must have resulted from shearing in the bedrock caused by the over-riding glacier. The water which deposited the sand flowed in a southerly direction, since the fractures open to the north. This, and the fractures that are in- 


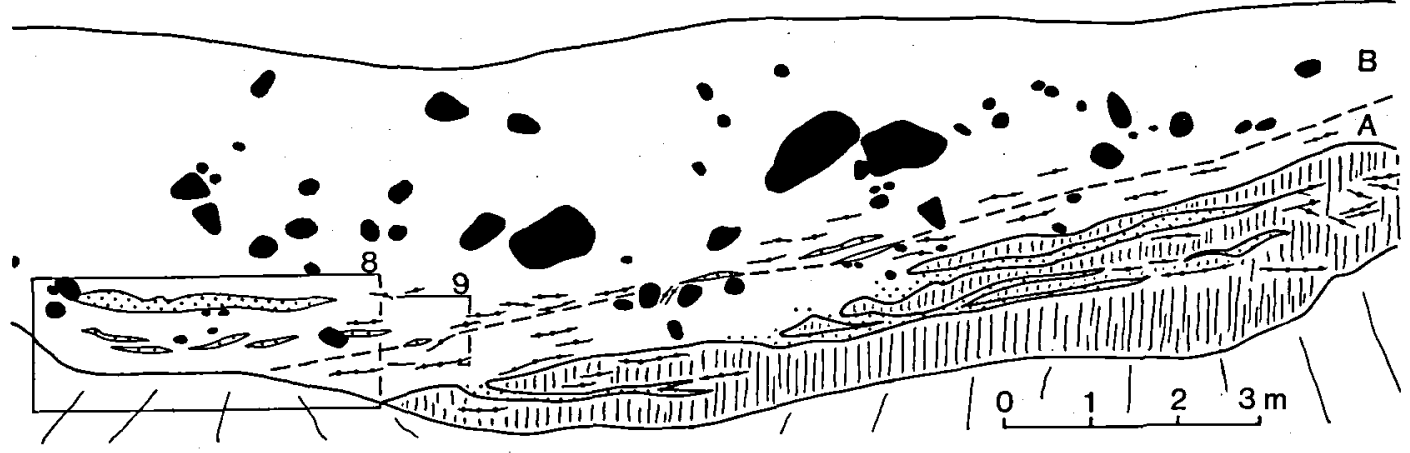

囵 Bedrock. Syenite

A Till. Rich in syenite

[B] Till. Poor in syenite

$\theta$ s and

Fig. 7. Survey of section 4 . The framed areas are covered by Figs. 8 and 9.

clined relative to the bedrock surface, indicate southward movement of the glacier. The neighbouring glacial striae support this observation. The sand-filled fractures and the gradual transitions between the bedrock and the till, show that the lower part of the till was deposited in direct contact with the bedrock. The overlying till could not have been deposited on ice and later let down to its present position. For, had a large body of stagnant ice occured beneath the sediments, erosion of the local bedrock would not have taken place (see below). Moreover, the boundary between till, rich in syenite and syenite-poor till would not coincide with the tops of the bedrock knobs (Fig. 2A) even if only small bodies of ice occured. It follows that no ice, or only minor bodies of ice, can have existed beneath already deposited material. The same conclusion can be drawn from the genesis of the strata and bodies of sand discussed below.

The folds and the low-angle faults were not due to flowing. The faults indicate a southerly di-

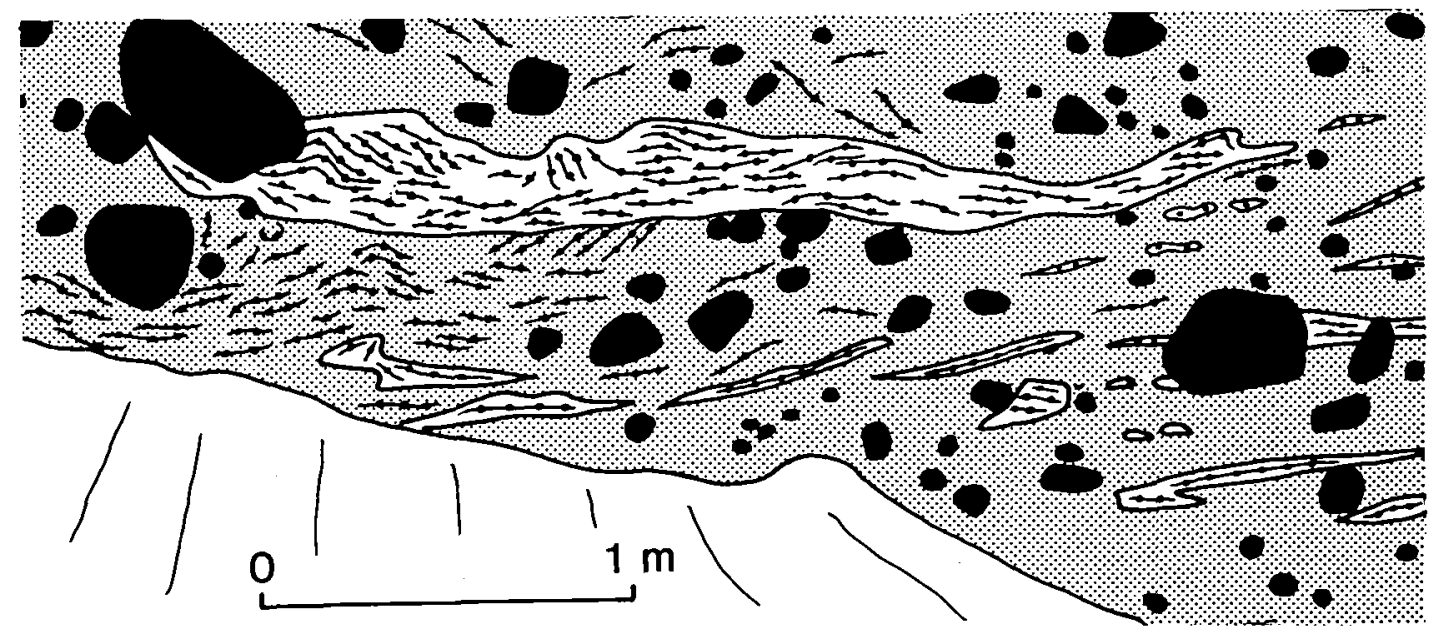

Boulder, stone Sand with distinct lamination
Poorly sorted material with diffuse strata and bodies of sand

Fig. 8. Well-defined strata of laminated sand in section 4. The figure covers the rectangle numbered 8 in Fig. 7. 


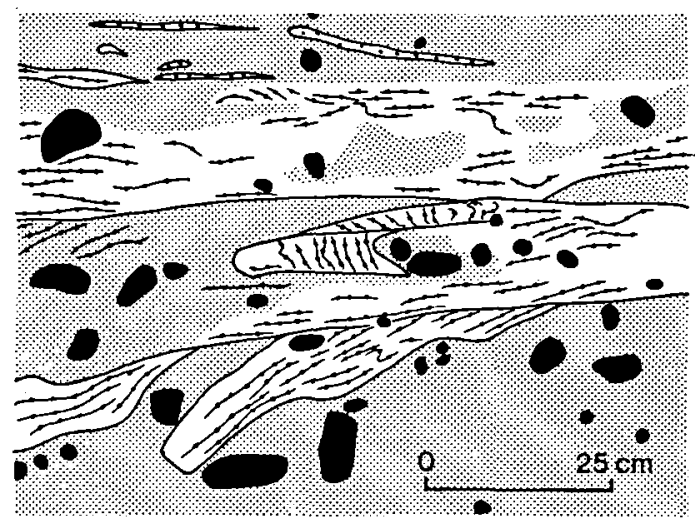

Poorly sorted material with diffuse strata and bodies of sand

Stone, boulder

Sand. Distinct lamination

Sand. Diffuse lamination

Distinct boundary

Diffuse boundary

Fig. 9. Distinctly and diffusely laminated strata of sand in section 4. More or less deformed strata occur in one and the same vertical profile. The figure covers the rectangle marked with the number 9 in Fig. 7.

rected deformational force. As the original dip of the beds was the same as today, this deformation was directed up-slope and could therefore only have been caused by a glacier in motion.

From the gradual transitions between well-defined strata of sand with distinct lamination and irregular strata with diffuse lamination, it can be observed that the latter resulted from the deformation of the former. Also, the gradual transitions between poorly sorted or unsorted sandygravelly material and sand or gravel, indicate deformation and mixing.

The laminated strata of sand are clearly depositional features. The gravel must therefore, at least to some extent be erosional remnants of a more unsorted material.

The alternating occurence of undisturbed and disturbed stratified drift in one and the same vertical profile means that: 1 . Deformation and accumulation were simultaneously acting processes. 2 . Sedimentation took place between the base of the glacier and already deposited material. 3. The accumulation was gradually upwards. This upward accumulation is also revealed in the extension of the undisturbed sand strata which is mainly parallel to the bedrock surface, and in the gradual transition between the lower and the upper till (see below).

As the undisturbed strata of sand are laminated parallel to their extension, one may assume that sedimentation took place in thin sheets, which only require a thin gap between the base of the glacier and already deposited material.

The petrographic composition of the till at the site $800 \mathrm{~m}$ east of Grönalund quarry, along with the coincidence between the tops of the syenite bedrock knobs and the till, rich, respectively poor, in syenite, leads to two conclusions. Firstly, the syenite in the lower till has been locally eroded. Secondly, the gradual boundary between the lower and upper till occured by the gradual covering of the syenite bedrock by till. Consequently, the glacier eroded the local bedrock, transporting and depositing fragment of it, simultaneously with the accumulation of sorted material during the formation of the lower till. The erosion took place at the protruding bedrock knobs and the deposition inbetween them. The poorly stratified and poorly sorted material resulted from the mixing and disturbance of simultaneously deposited stratified drift.

Since the absolute majority of particles coarser than $3 \mathrm{~mm}$ in the upper till, was carried at least 5 $\mathrm{km}$, they must have been englacially transported and melted out from the glacier. The occurence of more or less disturbed strata of stratified drift in the upper till, indicates that the glacier was active and shows the influence of running water on the melted out debris. The unsorted and massive parts of the upper till are partly a result of direct melt-out and partly of severe disturbance of the sorted material. Direct melt-out must have been responsible for the massive, unsorted bodies that are surrounded by sand with clearly visible lamination.

Limestone fragments are almost completely absent in the tills. Rapid melting at the base of a glacier, which results in a short transport of eroded material, explains this.

Acknowledgements. I would like to thank C. Hjort, Lund, who kindly read the manuscript. I am also grateful to T. Press for correcting the English language of the manuscript. 


\section{Dansk sammendrag}

To moræneaflejringers sammensætning og struktur er undersøgt ved Grönalund i Skåne. Morænerne hviler på et underlag af syenitiske bjergarter med ujæun overflade. Den nedre moræne indeholder over $80 \%$ syenitiske bjergarter (fraktion 3-11 $\mathrm{mm}$ ) af lokal oprindelse og er aflejret $\mathrm{i}$ lavningerne mellem opragende bjergartsknuder.

Den øvre moræne er i sin øverste del helt uden syeniter, og fragmenterne består næsten udelukkende af graniter og gnejser, der må vare transporteret mindst $5 \mathrm{~km}$ inden aflejringen har fundet sted.

Begge moræner indeholder uregelmæssige legemer af smeltevandsaflejringer, hvis strukturer tyder på en subglacial dannelse og en næsten samtidig glacial deformation, hvilket har medført, at morænerne er dårligt sorterede og viser en utydelig lamination.

På grund af lejringsforholdene og aflejringernes strukturer vises det, at morænerne er dannet ved udsmeltning fra en aktiv gletscher fra nordøstlig retning.

\section{References}

Bergström, J. \& Shaik, N. A. 1980: Malmer, indistruella mineral och bergarter i Kristianstad län. Sver. Geol. Unders. Rapp. och medd. nr. 22, 89 pp.
Boulton, G. S. 1970: On the deposition of subglacial and meltout tills at the margin of certain Svalbard glaciers. J. Glaciol. 56, 231-245.

Boulton, G. S. \& Dent, D. L. 1974: The nature and rates of post-depositional changes in recenly deposited till from south-east Iceland. Geogr. Ann. 56A, 121-134.

Boulton, G. S., Dent, D. L. \& Morris, E. M. 1974: Subglacial shearing and crushing, and the role of water pressures in tills from south-east Iceland. Geogr. Ann. 56A, 135-145.

Humlum, O. 1979: 'Fluted moraine' på Omø - isbevegelsesretning og aflejringsområde. Dansk geol. Forent., Årsskrift for $1978,15-22$.

Kornfält, K. A., Bergström, J., Carserud, L., Henkel, H. \& Sundquist, B. 1978: Beskrivning till berggrundskartan coh flygmagnetiska kartan Kristianstad SO. Sver. Geol. Unders. Ser. Af nr. 121, 120 pp.

Krüger, J. 1979: Structures and textures in till indicating subglacial deposition. Boreas 8, 323-340.

Krüger, J. \& Humlum, O. 1980: Deformations- og erosionsstrukturer i bundmorænelandskapet ved Mýrdalsjökull, Island. Dansk geol. Foren., Årsskrift for 1979, 31-39.

Shaw, J. 1977: Till body morphology and structure related to glacier flow. Boreas 6, 189-201.

Shaw, J. 1979: Genesis of the Sveg tills and Rogen moraines of central Sweden: a model of basal melt out. Boreas 8, 409426.

Sugden, D. E. \& John, B. S. 1976: Glaciers and landscape. 376 pp. Edward Arnold Ltd., London. 